\title{
Differences of Discipline Level Between Students from State and Private Junior High School in Malang City
}

\author{
Adi Slamet Kusumawardana \\ Program Study of Mathematics Education \\ University of Muhammadiyah Malang \\ Malang, Indonesia \\ adikusuma@umm.ac.id
}

\begin{abstract}
This research aimed to describe the difference of discipline level of Junior High School Students between State Junior High School and Private Junior High School in Malang. The level of discipline is seen from the punishment that the teacher gives to the student and the level of that intensity. This research is a descriptive research. Data questionnaires that have been filled by students are analyzed descriptively. The subject of this research is 1 class of students of $2^{\text {nd }}$ grade from each 4 junior high school in Malang. That 4 selected school are 2 state junior high schools and 2 private junior high schools. 2 state junior high schools are state junior high school (SJHS) 4 and state junior high school (SJHS) 20, while 2 selected private junior high school (PJHS) are PGRI 3 junior high school and Muhammadiyah 1 junior high school. Data collection is done by quantitative method through filling questionnaire. The steps of this study are problem identification, school observation, fill out a questionnaire, and questionnaire data analysis. Based on the results of research can be concluded that generally state junior high school's students a little more discipline than students from private junior high school. It is shown from the type of punishment and the intensity of receiving punishment received by state junior high school's students less than private junior high school's students.
\end{abstract}

Keywords: level of discipline, state junior high school, private junior high school

\section{INTRODUCTION}

Student discipline is very important in the learning process at school. Teaching activities by teachers will obviously be disrupted if students are not disciplined and often break the rules. Enforcement of discipline is also very necessary in order to achieve learning objectives. discipline is clearly influential in student achievement and motivation [1].

Student discipline is clearly a shared responsibility between the school and the parents. The school is certainly the teacher who teaches in the most important class, but the teacher is not alone, the guidance and counseling also influential in disciplining students [2], [3]. In addition to the school, the role of parents is also very necessary. In addition to school, children's learning time is also not rare when at home. The role of parents is often less aware by parents of students, whereas there is a positive influence between parent and teacher cooperation with the discipline of junior high school students. [4].

In discipline enforcement, many things done by the school and parents such as increasing student activity, educating hard, giving many regulations, and punish the students. Provision of punishment in general affects the discipline of students in learning in school [5]. From these influences, it can be assumed that the more students punished teachers, the more students are not disciplined in school. State Junior High School and Private Junior High School have differences in the ability of students, students' learning interests in sports [6], teachers, infrastructure and funding support. Private junior high school (PJHS) students generally have less ability than students of State junior high school (SJHS). This study aims to describe the differences in the discipline level of students of SJHC and PJHS measured by the punishment of the students and the intensity.

\section{RESEARCH METHOD}

This research was conducted through a survey of 4 Junior High Schools (SMP) in Malang. The method of choosing Junior High School which is the subject of research using Purposive Sampling. The chosen junior high schools are 2 state junior high schools (SJHS) and 2 private junior high schools (PJHS). SJHS 4 representing Lowokwaru sub-district, SJHS 20 representing Blimbing sub-district, PJHS PGRI 3 representing Sukun subdistrict and Junior High School of Muhammadiyah 1 representing sub-district of Klojen.

This research is descriptive research. The steps of this research are: (1) identification problem, (2) observation to school, (3) questionnaire distribution, and (4) questionnaire data analysis. Problem identification was done to see what problems happened to students in junior high school. The result of problem identification is the level of discipline of junior high school students, both public and private junior high schools are generally still low. School observations are conducted to determine the class that will be the subject of the research as well as to see the student's activities and trace the punishments punishments that students usually get if not disciplined. The division of questionnaires was conducted in 1 class which was the subject of the study. Selection of class using simple random sampling. After the data collected, conducted data analysis questionnaire.

The research instrument used are interview and questionnaire. Interview data is used to record what punishments are generally accepted by students. The punishment students receive and the intensity used to review the extent of student discipline. If the Student is disciplined, students rarely or even never receive punishment from the teacher, and if the student 
tends to be undisciplined, it certainly appears from the punishment what ever and often he received from the teacher. The questionnaire data was designed with a 1-5 scale answer containing the types of student penalties and their intensities: from "Never" to "Often". Questionnaire data obtained from respondents will be analyzed descriptively.

\section{RESUlt AND DISCUSSION}

\section{Identification Problem}

The result of problem identification that is obtained is the lack of discipline level of junior high school students in Malang City which is shown from interview result done to some Teachers and Students. Interviews also obtained that generally punishment received by students if not discipline is (1) Beaten Teacher, (2) Ear tweaked, (3) Pinched, (4) Sentenced to run, (5) Sentenced to dry in Field, (6) Scolded / Snapped (7) Exiled in class.

\section{School Observation}

School observations are conducted to determine which schools will be the subjects of the study and also to follow up on information obtained during interviews on punishment for students who are not disciplined in the School. In determining the school that will be the subject of research, conducted observations to several schools in the city of Malang is divided into 5 districts namely Blimbing district, Lowokwaru district, Klojen district, Sukun district, and Kedungkandang district. At school selection, based on social and economic conditions. In general the condition of 4 subdistricts namely Sukun, Blimbing, Klojen, and Lowokwaru almost the same, that is the area close to the city center and more crowded than Kedungkandang sub-district which is relatively far from the city center and the location of the area which tend to be deserted and hilly because it is located near the mountain Buring. From the consideration of homogeneity, selected 4 districts that became the target of research and research subjects taken schools that represent the 4 districts. SJHS 20 was chosen, representing Blimbing sub-district, SJHS 4 representing Lowokwaru sub-district, Junior High School of Muhammadiyah 1 representing Klojen sub-district, and PJHS PGRI 3 representing Sukun sub-district. From here will be compared between state junior high school and private junior high school.

From the observation also obtained information about the punishment - punishment received by students in schools that are divided into two parts namely physical punishment and non-physical punishment. The data becomes the grid of the questionnaire to be assigned to the students.
TABLE 1. SUBJECT MATTER IN QUESTIONNAIRE

\begin{tabular}{lll}
\hline \multicolumn{2}{c}{ Punishment } \\
\hline 1. & Physical Punishment \\
& a. & Beaten \\
b. & Ear tweaked \\
c. & Pinched \\
d. & Sentenced to Run \\
e. & Sentenced to Push up \\
f. & Sentenced to Bask \\
\hline Mental Punishment \\
a. & Verbal Bullying \\
b. & Shouted by Teacher \\
c. & Threatened by teacher \\
d. & Alienated \\
\hline
\end{tabular}

The material to be included in the questionnaire is the kinds of punishment contained in Table 1. The first point is to measure students' disciplinary levels in terms of punishments received by students in the form of corporal punishment and the second point is in terms of non-physical punishment received by students. In addition to seeing the types of punishment that is physical and non-physical, also note the intensity or level of frequency of students get punished by the teacher. This intensity is divided into 5 levels of frequency, ie "Never", "Rarely", "Sometimes", "Frequently", "Often Once". From the intensity level of receiving punishment, it can be known to what extent the level of frequency of students violating the rules of teachers or schools. Increasingly, breaking the rules indicates that the more undisciplined, and vice versa, if never punished by the teacher, it can be assumed that the student is disciplined in the school.

\section{Questionnaire Distribution}

Questionnaires were distributed to 4 junior high schools in Malang, namely SJHS 4, SJHS 20, PJHS PGRI 3, and Junior high school of Muhammadiyah 1. From each school, one class was selected randomly as respondents. From SJHS 4 selected one class containing 32 students, from SJHS 20 selected one class of 36 students, from PJHS PGRI 3 class of respondents containing 27 students, and from Junior High School of Muhammadiyah 1 contains 14 students. The questionnaire is given at about one hour of face-to-face meetings containing introductory, core activities, and cover. A face-to-face meeting was held on 4 days in August 2017. The face-to-face meeting contains introductory activities, which are self-introductions and activities to students in the classroom. The introductory activity takes about 10 minutes and is followed by the core activity of distributing questionnaires directly filled by the students. This activity lasts about 30 to 45 minutes. The meeting was closed by checking the questionnaire and greeting which lasted about 5 to 10 minutes.

\section{Data Analysis}

Data Analysis The questionnaire was conducted to find out the conclusions that can be obtained from the answers of the students questionnaires. The questionnaire was analyzed descriptively by calculating the frequency of answers on each question in the questionnaire. The data of questionnaires of observations will be compared between SJHS and PJHS. 
TABLE 2. DATA OF SJHS 4

\begin{tabular}{|c|c|c|c|c|c|}
\hline Question & \multicolumn{5}{|c|}{ Percentage of Answers } \\
\cline { 2 - 6 } number & 1 & 2 & 3 & 4 & 5 \\
\hline \multicolumn{7}{|c|}{ Physical Punishment } \\
\hline a. & 96.9 & 3.1 & 0 & 0 & 0 \\
\hline b. & 90.625 & 9.375 & 0 & 0 & 0 \\
\hline c. & 71.875 & 21.875 & 6.25 & 0 & 0 \\
\hline d. & 96.875 & 0 & 3.125 & 0 & 0 \\
\hline e. & 65.625 & 31.25 & 3.125 & 0 & 0 \\
\hline f. & 84.375 & 15.625 & 0 & 0 & 0 \\
\hline Mental Punishment \\
\hline a. & 59.375 & 37.5 & 3.125 & 0 & 0 \\
\hline b. & 40.625 & 40.625 & 18.75 & 0 & 0 \\
\hline c. & 87.5 & 6.25 & 0 & 6.25 & 0 \\
\hline d. & 93.75 & 6.25 & 0 & 0 & 0 \\
\hline
\end{tabular}

TABLE 3. DATA OF SJHSS 20

\begin{tabular}{|c|c|c|c|c|c|}
\hline \multirow{2}{*}{$\begin{array}{c}\text { Question } \\
\text { number }\end{array}$} & \multicolumn{5}{|c|}{ Percentage of Answers } \\
\cline { 2 - 6 } & 1 & 2 & 3 & 4 & 5 \\
\hline \multicolumn{2}{|c|}{ Physical Punishment } \\
\hline a. & 91.67 & 8.34 & 0 & 0 & 0 \\
\hline b. & 63.89 & 22.22 & 13.89 & 0 & 0 \\
\hline c. & 69.44 & 25 & 5.56 & 0 & 0 \\
\hline d. & 58.33 & 33.33 & 8.33 & 0 & 0 \\
\hline e. & 69.44 & 16.67 & 13.89 & 0 & 0 \\
\hline f. & 88.89 & 8.33 & 2.78 & 0 & 0 \\
\hline Mental Punishment & \multicolumn{5}{|l}{} \\
\hline a. & 83.33 & 13.89 & 2.78 & 0 & 0 \\
\hline b. & 30.56 & 58.33 & 11.11 & 0 & 0 \\
\hline c. & 94.44 & 5.56 & 0 & 0 & 0 \\
\hline d. & 94.44 & 5.56 & 0 & 0 & 0 \\
\hline
\end{tabular}

TABLE 4. DATA OF PJHS PGRI 3

\begin{tabular}{|c|c|c|c|c|c|}
\hline \multirow{2}{*}{$\begin{array}{c}\text { Question } \\
\text { number }\end{array}$} & \multicolumn{5}{|c|}{ Percentage of Answers } \\
\cline { 2 - 6 } & 1 & 2 & 3 & 4 & 5 \\
\hline \multicolumn{6}{|c|}{ Physical Punishment } \\
\hline a. & 40.75 & 59.56 & 3.71 & 0 & 0 \\
\hline b. & 33.33 & 51.851 & 14.82 & 0 & 0 \\
\hline c. & 22.22 & 59.26 & 11.11 & 3.71 & 3.71 \\
\hline d. & 48.15 & 40.74 & 3.71 & 7.41 & 0 \\
\hline e. & 66.67 & 25.93 & 7.41 & 0 & 0 \\
\hline f. & 96.3 & 3.71 & 0 & 0 & 0 \\
\hline Mental Punishment & 70.37 & 18.52 & 11.11 & 0 & 0 \\
\hline a. & 33.33 & 48.15 & 18.82 & 0 & 0 \\
\hline b. & 62.96 & 33.33 & 3.71 & 0 & 0 \\
\hline c. & 92.59 & 3.71 & 3.71 & 0 & 0 \\
\hline d. &
\end{tabular}

TABLE 5. DATA OF JUNIOR High SCHOOL OF MUHAMMADIYAH 1

\begin{tabular}{|c|c|c|c|c|c|}
\hline \multirow{2}{*}{$\begin{array}{c}\text { Question } \\
\text { number }\end{array}$} & \multicolumn{5}{|c|}{ Percentage of Answers } \\
\cline { 2 - 6 } & 1 & 2 & 3 & 4 & 5 \\
\hline Physical Punishment \\
\hline a. & 35.71 & 42.86 & 21.43 & 0 & 0 \\
\hline b. & 28.6 & 50 & 21.43 & 0 & 0 \\
\hline c. & 14.29 & 35.71 & 50 & 0 & 0 \\
\hline d. & 50 & 35.71 & 14.29 & 0 & 0 \\
\hline e. & 42.86 & 42.86 & 14.29 & 0 & 0 \\
\hline f. & 92.86 & 7.14 & 0 & 0 & 0 \\
\hline Mental Punishment & 57.14 & 28.57 & 14.29 & 0 & 0 \\
\hline a. & 5.14 & 50 & 35.71 & 7.14 & 0 \\
\hline b. & 71.43 & 14.29 & 7.14 & 7.14 & 0 \\
\hline c. & 100 & 0 & 0 & 0 & 0 \\
\hline d. & 100 &
\end{tabular}

Observation results of 32 students of SJHS 4, obtained information that in general SJHS 4 students have never been punished by teachers, this is indicated by questions (a), (b), (d) on physical punishment and mental punishment point (d) known to almost all students replied never to be seen from the percentage of students who have ever been punished over $90 \%$. The same thing can be seen in the next SJHS 20. Of 36 students Sjhs 20, obtained the same information that in general SJHS 20 students never punished teachers, shown by student answers on almost all questions about physical and psychological violence there are more of the $50 \%$ of students who answered were never punished. And only 1 point is the question of the punishment of mental points (b) only the results are different.

Compared with the answer of Private Junior High School (PJHS) students, there is a significant difference of answers. From 27 students of PJHS PGRI 3 obtained information in general PGRI 3 junior high school students have ever punished by teachers. This can be seen in the answers to the questions of points (a), (b), (c), (d) related to corporal punishment and question points (b) indicates that more than half the students have been punished by the teacher, which can be seen from the percentage of " never "averaged less than $50 \%$ and the rest answered ever though almost all in the" rare "category. The same can be seen from the results of other private junior high school questionnaires, namely Junior High School of Muhammadiyah 1. From the results of 14 students are obtained information that in general students JHSM 1 have ever punished by teachers. This can be seen from the answers of the student questionnaires to the question of points (a), (b), (c), (e) about physical punishment and question point (b) which is more than $50 \%$ percent have ever received a penalty.

Student questionnaire data SJHS 4 shows that the punishment of the most widely accepted students is mental punishment, that is shouted by teachers with a percentage of $59.375 \%$, while the most received physical punishment of students is a penalty push-up with a percentage of $34.375 \%$.

Student questionnaire data SJHS 20 shows that the punishment is the most widely accepted students is a mental punishment that shouted by the teacher with a percentage of $69.44 \%$. For the most widely accepted physical punishment the student is sentenced to run with a percentage of $41.66 \%$.

Student questionnaire data PJHS PGRI 3 shows that the punishment is the most widely accepted students is a physical punishment, that is pinched by teacher. On the question of this point all categories containing the intensity of receiving punishment are all filled with the highest percentage of "rare" intensity with percentage $59.26 \%$.

The questionnaire data of JHSM 1 students showed slightly different results compared to 3 other schools, which is a small percentage of students who never received the punishment. The punishment that is often accepted by students is physical punishment in the form of being hit by teachers with percentage of $71.43 \%$.

From the analysis of questionnaires data obtained the conclusion that the punishment of the most widely accepted junior high school students different from Private Junior High 
School. In general, the punishment of the most accepted junior high school students in the form of psychological punishment, while for private junior high school students is the most physical punishment. This is certainly the impact of the different entrance filters and student abilities.

\section{CONCLUSION}

The result of problem identification is the lack of discipline level of junior high school students in Malang City which is shown from interview result done to some Teachers and Students. Interviews also obtained that generally punishment received by students if not discipline is (1) Beaten Teacher, (2) Ear Tweaked, (3) Pinched, (4) Sentenced to run, (5) Sentenced to dry in Field, (6) Scolded / Snapped (7) From the results of field observation found that in addition to the physical punishment that is ridiculed friends, barked teachers, threatened teachers, and ostracized or exiled. To dig deeper information was done the distribution of questionnaires to 4 junior high schools in Malang with details of 2 State Junior High School (SJHS) and 2 Private Junior High School (PJHS). The results of the 4 schools will be compared between the questionnaires of the students of SJHS and PJHS students. From the data analysis, it can be concluded that most of state junior high school students are never punished by teachers. The opposite occurs in Private Junior High School where most students have been punished by teachers. The punishment that many students of SJHS and PJHS receive is also different. State Junior High School students receive the most punishment in the form of mental punishment, while private junior high school students receive the most punishment in the form of physical punishment.

\section{REFERENCES}

[1] Haryono. Sugeng. "Pengaruh Kedisiplinan Siswa dan Motivasi Belajar terhadap Prestasi Belajar Siswa pada Mata Pelajaran Ekonomi”, Faktor Jurnal Ilmiah Kependidikan. Vol. 3, pp. 261-274,2016.

[2] F.J. FIana, Daharnis, and M. Ridha. "Disiplin Siswa di Sekolah dan Implikasinya dalam Pelayanan Bimbingan dan Konseling”, Konselor Jurnal Ilmiah Konseling. vol. 2, pp 26-33, 2013.

[3] S. Masruroh. "Upaya Peningkatan Kedisiplinan Masuk Kegiatan Belajar Mengajar Melalui layanan Konseling Individu Pada Siswa Kelas VII H SMP Negeri 4 Surakarta Semester Satu Tahun 2011/2012”, Journal Ilmiah Pembelajaran. vol 6, pp 1-11, 2009.

[4] H. S. Hidayat. "Pengaruh Kerjasama Orang Tua dan Guru terhadap Disiplin Peserta Didik di Sekolah Menengah Pertama (SMP) Negeri Kecamatan Jagakarsa - Jakarta Selatan", Jurnal Ilmiah WIDYA. vol. 1, pp.92-99,2013.

[5] M. Ardi. "Pengaruh Pemberian Hukuman Terhadap Disiplin Siswa Dalam Belajar", Jurnal EKSOS. vol. 8, pp. 61-72,2012.

[6] S.P. Saputro. "Perbandingan Minat Belajar Antara Siswa Sekolah Negeri dan Sekolah Swasta dalam Permainan Sepakbola", Jurnal Pendidikan Olahraga dan Kesehatan. vol. 1,pp. 672-676, 2013. 